\title{
THE ROLE OF QUATERNARY CYTOREDUCTION IN RELAPSED OVARIAN CANCER - A SYSTEMATIC REVIEW
}

\author{
Nicolae BACALBASA ${ }^{1,2,3 凶}$, Irina BALESCU ${ }^{4,5}$, Mihaela VILCU ${ }^{1,6}$, loana HALMACIU, \\ Camelia C. DIACONU ${ }^{1,8}$, Simona DIMA ${ }^{3}$, Iulian BREZEAN ${ }^{1,6}$
}

1 „Carol Davila“ University of Medicine and Pharmacy, Bucharest, Romania

${ }^{2}$ Department of Obstetrics and Gynecology, „I. Cantacuzino“ Clinical Hospital, Bucharest, Romania

${ }^{3}$ Department of Visceral Surgery, Center of Excellence in Translational Medicine „Fundeni“ Clinical Institute, Bucharest, Romania

${ }^{4}$ Department of Surgery, „Ponderas“ Academic Hospital, Bucharest, Romania

5 „Carol Davila“ University of Medicine and Pharmacy, Bucharest, Romania

${ }^{6}$ Department of Visceral Surgery, „I. Cantacuzino“ Clinical Hospital, Bucharest, Romania

7 Department of Anatomy, „George Emil Palade“ University of Medicine, Pharmacy, Science and Technology, Targu Mures, Romania

${ }^{8}$ Department of Internal Medicine, Clinical Emergency Hospital of Bucharest, Bucharest, Romania

Received 18 Febr 2020, Accepted 25 Apr 2020

https://doi.org/10.31688/ABMU.2020.55.2.13

\section{Abstract}

Introduction. Ovarian cancer is characterized by a high capacity of relapse, even in cases in whom cytoreductive surgery with curative intent followed by platinum and taxanes-based chemotherapy were performed. In such cases, attention was focused on determining if iterative cytoreduction might improve the long-term outcomes and how far these boundaries can be pushed. While for secondary cytoreduction multiple studies have been conducted, for tertiary and quaternary cytoreduction data are significantly scarcer.

The objective of the study. This paper aims to realize a systematic review of the studies published so far on the theme of quaternary cytoreduction.

Methodology. We searched medical journals in English language published from January 2010 to December 2019.

\section{RÉsumé}

Le rôle de la cytoréduction quaternaire dans le cancer ovarien en rechute - une revue systématique

Introduction. Le cancer de l'ovaire se caractérise par une forte capacité de rechute, même dans les cas où une chirurgie cyto-réductible à visée curative suivie d'une chimiothérapie à base de platine et de taxanes soit effectuée. Dans de tels cas, l'attention a visé de déterminer si la cytoréduction itérative pourrait améliorer les résultats à long terme et jusqu'à quelles limites ils peuvent aller. Tandis que pour la cytoréduction secondaire, plusieurs études ont été menées sur cette question, pour la cytoréduction tertiaire et quaternaire, les données sont nettement plus rares.

L'objectif de l'étude. Le but de cette article est de réaliser une revue systématique des études publiées 
Results. Six studies involving 110 patients submitted to quaternary cytoreduction met the inclusion criteria. Data reported in the above mentioned studies demonstrate that quaternary cytoreduction can be safely performed both at the level of the lower and the upper abdomen, in order to maximize the debulking effort. However, a significantly lower number of cases will be considered candidates for this type of procedure, when compared to secondary or even tertiary cytoreduction, an adequate selection process being mandatory in order to minimize the postoperative risks.

Conclusions. Although it is less frequently feasible when compared to secondary or tertiary cytoreduction, quaternary cytoreduction might be beneficial in selected cases.

Keywords: quaternary, debulking, ovarian cancer, survival.

\section{INTRODUCTION}

Ovarian cancer is one of the most aggressive gynecological malignancies, affecting women worldwide, usually diagnosed in advanced stages of the disease; due to the fact that it usually remains asymptomatic for a long period of time, ovarian cancer has been considered as a silent killer ${ }^{1,2}$. In order to prolong the survival of these patients, the principles of debulking surgery, initially proposed by Meigs and later on demonstrated by Griffiths, became the standard of care in such cases ${ }^{3,4}$. As for the diameter of the residual volume, this parameter has suffered permanent changes; although initially it has been established at $2 \mathrm{~cm}$, it was systematically decreased to 1.5 $\mathrm{cm}, 1 \mathrm{~cm}, 0.5 \mathrm{~cm}$, while nowadays most authors consider that residual disease should be no longer visible at the end of the debulking process ${ }^{5-7}$. Another issue strongly debated was the one of the tumor biology; therefore, it has been initially considered that cases presenting upper abdominal lesions present in fact a more aggressive tumoral biology when compared to cases presenting pelvic limited disease. However, this theory was rapidly abandoned since it has been demonstrated that if the principles of complete debulking surgery are achieved, similar long-term survival rates can be expected in both categories of patients ${ }^{8,9}$.

One of the most important issues that affect these patients is the one of relapse. Even if debulking jusqu'à présent sur le thème de la cytoréduction quaternaire.

Méthodes. Nous avons cherché dans les revues médicales en langue anglaise publiées de janvier 2010 à décembre 2019.

Résultats. Six études portant sur 110 patients soumis à une cytoréduction quaternaire répondaient aux critères d'inclusion. Les données rapportées dans les études mentionnées ci-dessus viennent démontrer que la cytoréduction quaternaire peut être effectuée en toute sécurité à la fois au niveau de l'abdomen inférieur et supérieur afin de maximiser l'effort d'élimination. Cependant, un nombre significativement plus faible de cas sera considéré comme candidat pour ce type de procédure par rapport à une cytoréduction secondaire voire tertiaire, un processus de sélection adéquat étant obligatoire afin de minimiser les risques postopératoires.

Conclusions. Bien qu'elle soit moins fréquemment réalisable par rapport à la cytoréduction secondaire ou tertiaire, la cytoréduction quaternaire pourrait être bénéfique dans certains cas.

Mots-clés: quaternaire, cytoréduction, cancer de l'ovaire, survie.

to no residual disease is achieved and consolidated by the routine administration of taxanes and platinum-based chemotherapy, up to $70 \%$ of cases, who have been initially diagnosed in advanced stages of the disease, will recur ${ }^{10}$. In this context, attention was focused on determining whether the application of these principles can be taken into consideration in order to achieve a better survival. Therefore, the first studies and later on the first meta-analyses were published and demonstrated the efficacy and safety of debulking in the setting of recurrent ovarian cancer. However, recurrence developed even if debulking of the relapse occurred, and the next raised question was whether iterative cytoreduction is still justified. Patients who could benefit from tertiary cytoreduction have more often a poorer clinical and biological status and unfortunately are more frequently diagnosed with more disseminated lesions, which usually involve vital, unresectable structures ${ }^{11-15}$. Therefore, the number of cases who will benefit from tertiary cytoreduction is significantly lower when compared to those submitted to secondary cytoreduction. Even so, certain cases who are successfully submitted to tertiary cytoreduction might develop another recurrence and might be once again the subjects of a new cytoreduction $^{16-19}$. In all these groups of patients submitted to primary, secondary and even tertiary cytoreduction, together with the volume of residual disease, another parameter which seems to play a central 
role in influencing the long-term outcomes is represented by the disease-free survival interval; therefore, it has been widely demonstrated that patients who exhibit a disease-free survival interval of at least 6 to 12 months between iterative cytoreductions have a greater chance to achieve a better survival ${ }^{15}$.

The OBJective of the current systematic review is to analyze the published literature on the issue of quaternary cytoreduction and to determine the effect of different variables on the short-term and long-term outcomes of these patients. The main questions on which we focused in this review were related to the volume of residual disease at the time of quaternary cytoreduction, feasibility of lower abdominal resections, upper abdominal resections, the perioperative morbidity and mortality and to the long-term outcomes after quaternary cytoreduction.

\section{Methodology}

The design was guided by the Preferred Reporting Items for Systematic Review and Meta-Analyses statement (PRISMA) ${ }^{20,21}$. A comprehensive search of the medical literature published in English language between January 2010 and December 2019 was performed, querying both studies and abstracts published during this period. The research included MEDLINE, Scopus, Google Scholar, Cochrane library and clinicaltrials.gov. The keywords used were „quaternary cytoreduction“, „quaternary debulking“, „ovarian cancer“, „relapse“, and „recurrence“. The resulting papers were reviewed and specific exclusion criteria were applied: letters to the editor, animal studies, and non-English language published papers and case reports.

\section{Data extraction}

All data regarding the demographic characteristics, type of surgery, extent of surgery, residual disease, postoperative morbidity and mortality, long-term follow-up, disease-free survival and overall survival were extracted and analyzed. For any difficulty in understanding these results, corresponding authors were contacted via email.

\section{Results AND discussion}

The above mentioned search strategy resulted in 17 studies; of these studies, 11 articles were excluded due to different reasons: case reports - three studies, studies on animals - one study, studies in other languages than English - six studies, letters to the editor - one study. Finally, six articles were included in the current review.

The six reviewed studies included a total number of 110 patients submitted to quaternary cytoreduction.

The first study conducted on the theme of the feasibility of quaternary cytoreduction was published in 2010 and originated from Shih et al, that included 15 patients submitted to surgery between January 1990 and July 2008 at the Memorial Sloan-Kettering Cancer Center, New York, United States of America ${ }^{22}$. The median age at the time of quaternary debulking was 4 year older than at the time of initial diagnosis; while at the time of the initial diagnosis optimal cytoreduction was defined by a residual tumoral volume lower than $1 \mathrm{~cm}$, this volume was decreased to 0.5 $\mathrm{cm}$ at the time of secondary and tertiary cytoreduction and respectively to no visible residual disease at the time of quaternary cytoreduction, demonstrating once again the changes of this concept during the last decades. According to Shih's study, the desiderate of no residual disease was achieved in $66.7 \%$ of cases. At univariate analysis, the volume of the residual disease, as well as the number of recurrences (solitary versus multiple), were the most important predictors for the long-term outcomes; although cases in whom the residual disease was lower than $1 \mathrm{~cm}$ reported a significantly better outcome when compared to cases in which the residual disease was larger, this was no longer statistically significant when the analysis was conducted between cases in whom no visible residual disease was encountered when compared to cases left with visible residual tumor. However, this surprising result was explained by the authors through the low number of cases included in their study. Other studied factors, such as the time to first or second recurrence, as well as the extent of tertiary cytoreduction, did not significantly influence the overall survival. As for the long-term outcomes, the authors reported a median disease-free survival after quaternary cytoreduction of only 3.7 months, suggesting that these multiple surgically-treated patients are usually platinum-resistant cases $^{22}$. Studies published later on, which included larger series of patients, demonstrated that the absence of residual disease is in fact the most important predictive factor for achieving long-term survival after quaternary cytoreduction ${ }^{23-26}$.

Studies conducted so far on the theme of quaternary cytoreductive surgery are presented in Table 1.

As expected, the most important prognostic factor, which seemed to influence the long-term outcomes after quaternary cytoreduction, was represented by the completeness of debulking surgery at the time of the fourth attempt of debulking; other investigated factors, represented by age, FIGO stage 
Table 1. Studies conducted so far on the issue of quaternary cytoreduction.

\begin{tabular}{|c|c|c|c|c|c|c|c|c|c|}
\hline Name, year & $\begin{array}{l}\text { No of } \\
\text { cases }\end{array}$ & $\begin{array}{l}\text { Period of the } \\
\text { study }\end{array}$ & $\begin{array}{l}\text { Definition } \\
\text { of optimal } \\
\text { debulking }\end{array}$ & $\begin{array}{l}\text { Complete } \\
\text { tumor } \\
\text { resection } \\
\text { rate }\end{array}$ & $\begin{array}{l}\text { Postop- } \\
\text { erative } \\
\text { morbidity }\end{array}$ & $\begin{array}{l}\text { Postop- } \\
\text { erative } \\
\text { mortality }\end{array}$ & $\begin{array}{c}\text { Factors } \\
\text { influencing the } \\
\text { outcomes after } \\
\text { QC }\end{array}$ & $\begin{array}{c}\text { Disease free } \\
\text { survival } \\
\text { after QC }\end{array}$ & $\begin{array}{c}\text { Other investigated } \\
\text { factors with no sta- } \\
\text { tistical significance } \\
\text { of the long- term } \\
\text { outcomes }\end{array}$ \\
\hline Shih, $2010^{22}$ & 15 & $1991-2008$ & $\begin{array}{c}\text { No visible } \\
\text { residual } \\
\text { disease }\end{array}$ & $66.7 \%$ & $\begin{array}{c}46 \% \\
\text { (overall) }\end{array}$ & 0 & $\begin{array}{l}\text { Residual } \\
\text { disease } \\
\text { No. of recur- } \\
\text { rences }\end{array}$ & 3.7 months & $\begin{array}{l}\text { Time to first and } \\
\text { second recurrence } \\
\text { Extent of tertiary } \\
\text { cytoreduction }\end{array}$ \\
\hline $\begin{array}{l}\text { Fotopoulou, } \\
2013^{23}\end{array}$ & 49 & $2000-2012$ & $\begin{array}{c}\text { No visible } \\
\text { residual } \\
\text { disease }\end{array}$ & $32.6 \%$ & $\begin{array}{l}28.6 \% \\
\text { (major } \\
\text { morbid- } \\
\text { ity) }\end{array}$ & $2 \%$ & $\begin{array}{c}\text { Residual } \\
\text { disease } \\
\text { Multifocal } \\
\text { lesions } \\
\text { Association } \\
\text { of CHT after } \\
\text { QC }\end{array}$ & $\begin{array}{c}22.5 \\
\text { months }\end{array}$ & $\begin{array}{c}\text { Age } \\
\text { Ascites } \\
\text { Extra-pelvic tumor } \\
\text { involvement } \\
\text { Grading } \\
\text { FIGO stage IIIC/ } \\
\text { IV versus lower at } \\
\text { the time of initial } \\
\text { diagnosis } \\
\text { Initial Platinum } \\
\text { response }\end{array}$ \\
\hline $\begin{array}{l}\text { Bacalbasa, } \\
2015^{24}\end{array}$ & 20 & $2002-2014$ & $\begin{array}{c}\text { No visible } \\
\text { residual } \\
\text { disease }\end{array}$ & $35 \%$ & $15 \%$ & 0 & $\begin{array}{l}\text { Completeness } \\
\text { of quaternary } \\
\text { cytoreduction }\end{array}$ & 16 months & NR \\
\hline $\begin{array}{l}\text { Hirakawa, } \\
2017^{25}\end{array}$ & 11 & $2000-2014$ & $\begin{array}{c}\text { No visible } \\
\text { residual } \\
\text { disease }\end{array}$ & $63 \%$ & NR & NR & NR & $\begin{array}{c}123 \\
\text { months } \\
\text { after } \\
\text { secondary } \\
\text { debulking } \\
\text { surgery }\end{array}$ & NR \\
\hline $\begin{array}{l}\text { Fanfani, } \\
2015^{26}\end{array}$ & 12 & $1997-2014$ & $\begin{array}{c}\text { No visible } \\
\text { residual } \\
\text { disease }\end{array}$ & $100 \%$ & NR & NR & $\begin{array}{l}\text { Completeness } \\
\text { of quaternary } \\
\text { cytoreduction, } \\
\text { treatment } \\
\text { free interval } \\
\text { larger than } 12 \\
\text { months }\end{array}$ & NR & $\begin{array}{l}\text { Pattern of recur- } \\
\text { rence }\end{array}$ \\
\hline
\end{tabular}

Legend: QC - quaternary cytoreduction; CHT - chemotherapy; FIGO - International Federation of Obstetrics and Gynecology.

at diagnosis, the presence of extra-pelvic disease or association of chemotherapy, failed to demonstrate a significant influence on the long-term outcomes.

However, patients submitted to adjuvant chemotherapy after quaternary cytoreduction tend to have a better outcome when compared to cases in whom surgery is no longer consolidated by the administration of systemic therapy ${ }^{23}$.

Regarding the rates of postoperative complications, in certain studies significant rates of postoperative morbidity might be encountered ${ }^{27,28}$; however, this fact is not difficult to be explained, due to the fact that cases who are included in such studies usually have a long history of surgical procedures and cytotoxic therapies $^{29-31}$. All this medical histories are therefore able to explain a particular reactivity and a particular condition of these cases. However, as it can be observed from the above mentioned data, the mortality rates remain low, encouraging the extension of the number of cases submitted to quaternary cytoreduction.

Quaternary cytoreduction was also reported in papers which investigated other subjects, such as the utility of anti-adhesions solutions after cytoreductive surgery; therefore, in a paper conducted by Krill et al, the authors included 375 patients submitted to cytoreduction for advanced stage or relapsed ovarian cancer, quaternary cytoreduction being performed in three cases. However, the study did not offer any information regarding the completeness of cytoreduction, the short-term or the long-term outcomes ${ }^{32}$.

Another interesting issue, which should be discussed in the setting of quaternary cytoreduction, is the involvement of the upper abdomen and the feasibility of upper abdominal resections at this time. As already mentioned, the upper abdominal involvement has been considered for a long period of time as a formal contraindication for resection in ovarian cancer patients. However, later on, the utility and safety of this procedure were clearly demonstrated. The studies which referred to the extent of the resection phase in the upper abdomen, as well as the related complications, are presented in Table 2 .

When it comes to the feasibility of upper abdominal resections, it seems that extending the resection 
Table 2. Studies referring to quaternary cytoreduction which detailed the gestures in the upper abdomen

\begin{tabular}{|c|c|c|c|}
\hline Name, year & No. of cases & Type of upper abdominal resections & Postoperative complications \\
\hline Fotopoulou, $2013^{23}$ & 49 & $\begin{array}{c}\text { Para-aortic lymph node dissection - 10.2\% } \\
\text { Partial liver resection - } 6.1 \% \\
\text { Liver capsule resection - } 2 \% \\
\text { Partial gastrectomy - } 2 \% \\
\text { Cholecystectomy }-4.1 \% \\
\text { Splenectomy - } 4.1 \% \\
\text { Diaphragmatic resection - } 2 \%\end{array}$ & $28.6 \%$ \\
\hline Bacalbasa, $2015^{24}$ & 20 & $\begin{array}{c}\text { Partial liver resection - 15\% } \\
\text { Splenectomy - 5\% } \\
\text { Partial gastrectomy - 5\% }\end{array}$ & $15 \%$ \\
\hline
\end{tabular}

at this level might be beneficial and is not associated with a significant increase of the specific morbidity and mortality. Therefore, in the study conducted by Fotopoulou et al, the most commonly performed upper abdominal resections were represented by partial liver resection or liver capsule resection, followed by splenectomy, cholecystectomy, diaphragmatic resection and partial gastrectomy ${ }^{23}$.

In a similar study conducted by Bacalbasa et al, the authors introduced 20 patients submitted to quaternary cytoreduction, the most commonly performed procedure at the level of the upper abdomen being represented by liver resection in 15\% of cases; postoperatively, complications due to upper abdominal resections occurred in a single case, demonstrating in this way the safety and feasibility of the method ${ }^{24}$.

\section{Conclusions}

Quaternary cytoreductive surgery seems to be safe and efficient in improving the long-term outcomes for relapsed ovarian cancer; most studies published so far demonstrated that the dimensions of the residual volume and the completeness of cytoreduction represent the most important prognostic factors, after such surgical procedures.

\section{Author contributions:}

I. B. and M.V. conceived the original draft preparation. N.B. and I. B. were responsible for conception and design of the review. I.H. and S.D. were responsible for the data acquisition. C.C.D. was responsible for the collection and assembly of the articles/published data, and their inclusion and interpretation in this review. All authors contributed to the critical revision of the manuscript for valuable intellectual content. All authors have read and agreed to the published version of the manuscript.

\section{Compliance with Ethics Requirements:}

„The authors declare no conflict of interest regarding this article"

\section{Acknowledgements:}

„This work was supported by the project entitled „Multidisciplinary Consortium for Supporting the Research Skills in Diagnosing, Treating and Identifying Predictive Factors of Malignant Gynecologic Disorders", project number PN-III-P1-1.2-PCCDI2017-0833."

\section{References}

1. Howlader N, Noone AM, Krapcho M, et al. SEER Cancer Statistics Review, 1975-2012, National Cancer Institute. Bethesda, MD. Available at http://seer.cancer.gov/ csr/1975_2012/(accessed 03 Febr 2020)

2. Jemal A, Siegel R, Xu J, Ward E. Cancer statistics, 2010. CA Cancer J Clin. 2010;60: 277-300.

3. Meigs JV. Tumors of the female pelvic organs. New York: MacMillan; 1934.

4. Griffiths CT. Surgical resection of tumor bulk in the primary treatment of ovarian carcinoma. Natl Cancer Inst Monogr. 1975;42:101-4.

5. Hoskins WJ, Bundy BN, Thigpen JT, Omura GA. The influence of cytoreductive surgery on recurrence-free interval and survival in small-volume stage III epithelial ovarian cancer: a Gynecologic Oncology Group study. Gynecol Oncol. 1992;47:159-66.

6. Hoskins WJ, McGuire WP, Brady MF, et al. The effect of diameter of largest residual disease on survival after primary cytoreductive surgery in patients with suboptimal residual epithelial ovarian carcinoma. Am J Obstet Gynecol. 1994;170:974-9.

7. Eisenkop SM, Friedman RL, Wang HJ. Complete cytoreductive surgery is feasible and maximizes survival in patients with advanced epithelial ovarian cancer: a prospective study. Gynecol Oncol. 1998;69:103-8.

8. Aletti GD, Dowdy SC, Gostout BS, et al. Aggressive surgical effort and improved survival in advanced-stage ovarian cancer. Obstet Gynecol. 2006;107:77-85.

9. Bristow RE, Tomacruz RS, Armstrong DK, Trimble EL, Montz FJ. Survival effect of maximal cytoreductive surgery for advanced ovarian carcinoma during the platinum era: a meta-analysis. J Clin Oncol. 2002;20:1248-59.

10. Chi DS, McCaughty K, Diaz JP, et al. Guidelines and selection criteria for secondary cytoreductive surgery in patients with recurrent, platinum-sensitive epithelial ovarian carcinoma. Cancer. 2006;106:1933-9.

11. Salani R, Santillan A, Zahurak ML, et al. Secondary cytoreductive surgery for localized, recurrent epithelial ovarian 
cancer: analysis of prognostic factors and survival outcome. Cancer. 2007; 109: 685-91.

12. Benedetti PP, De Vivo A, Bellati F, et al. Secondary cytoreductive surgery in patients with platinum-sensitive recurrent ovarian cancer. Ann Surg Oncol. 2007;14:1136-42.

13. Bristow RE, Chi DS. Platinum-based neoadjuvant chemotherapy and interval surgical cytoreduction for advanced ovarian cancer: a meta-analysis. Gynecol Oncol. 2006; 103: 1070-6.

14. Zang RY, Li ZT, Tang J, et al. Secondary cytoreductive surgery for patients with relapsed epithelial ovarian carcinoma: who benefits? Cancer. 2004;100:1152-61.

15. Bristow RE, Puri I, Chi DS. Cytoreductive surgery for recurrent ovarian cancer: a meta-analysis. Gynecol Oncol. 2009;112: 265-74.

16. Leitao MM Jr, Kardos S, Barakat RR, Chi DS. Tertiary cytoreduction in patients with recurrent ovarian carcinoma. Gynecol Oncol. 2004;95:181-8.

17. Karam AK, Santillan A, Bristow RE, et al. Tertiary cytoreductive surgery in recurrent ovarian cancer: selection criteria and survival outcome. Gynecol Oncol. 2007;104: 377-80.

18. Shih KK, Chi DS, Barakat RR, Leitao MM Jr. Tertiary cytoreduction in patients with recurrent epithelial ovarian, fallopian tube, or primary peritoneal cancer: an updated series. Gynecol Oncol. 2010; 117: 330-5.

19. Dogan NU, Schneider A, Chiantera V, Dogan S, Dursun P. Tertiary cytoreduction in the setting of recurrent ovarian cancer (Review). Oncol Lett. 2013;6:642-7.

20. Liberati A, Altman DG, Tetzlaff J, et al. The PRISMA statement for reporting systematic reviews and meta-analyses of studies that evaluate healthcare interventions: explanation and elaboration. BMJ. 2009;339: b2700.

21. Moher D, Liberati A, Tetzlaff J, Altman DG. Preferred reporting items for systematic reviews and meta-analyses: the PRISMA statement. BMJ. 2009;339: b2535.

22. Shih KK, Chi DS, Barakat RR, Leitao MM Jr. Beyond tertiary cytoreduction in patients with recurrent epithelial ovarian, fallopian tube, or primary peritoneal cancer. Gynecol Oncol. 2010;116:364-9.
23. Fotopoulou C, Savvatis K, Kosian P, et al. Quaternary cytoreductive surgery in ovarian cancer: does surgical effort still matter? Br J Cancer. 2013; 108: 32-8.

24. Bacalbasa N, Balescu I, Dima S, Brasoveanu V, Popescu I. The role of quaternary cytoreduction in recurrent epithelial ovarian cancer: a single-center experience. Anticancer Res. 2015;35:3519-23.

25. Hirakawa T, Minaguchi T, Itani Y, et al. Current status of tertiary debulking surgery and prognosis after secondary debulking surgery for recurrent Mullerian epithelial cancer in Japan: a retrospective analysis of 164 patients (KCOG-G1402). World J Surg Oncol. 2017;15:132.

26. Fanfani F, Fagotti A, Ercoli A, et al. Is there a role for tertiary (TCR) and quaternary (QCR) cytoreduction in recurrent ovarian cancer? Anticancer Res. 2015;35:6951-5.

27. Bodean $\mathrm{O}$, Bratu $\mathrm{O}$, Munteanu $\mathrm{O}$, et al. Iatrogenic injury of the low urinary tract in women undergoing pelvic surgical interventions. Arch Balk Med Union. 2018;53(2):281-284.

28. Diaconu CC, Arsene D, Balaceanu A, Bartos D. A rare tumor revealed by abdominal trauma: case presentation. Romanian Journal of Morphology and Embryology. 2014;55(3):973-976.

29. Tiglis M, Neagu TP, Elfara M, et al. Nefopam and its role in modulating acute and chronic pain. Rev Chim. 2018;69(10):2877-2880.

30. Dumitras IC, Ionescu C, Bartos D, Diaconu C. The diagnosis of malignant disease: sometimes a matter of pure chance. Arch Balk Med Union. 2017;52(1):112-116.

31. Socea B, Nica AA, Bratu O, et al. Incidental finding of a sigmoid intussusception associated with rectal prolapse - a case report. Arch Balk Med Union. 2018;53(1):143-146.

32. Krill LS, Ueda SM, Gerardi M, Bristow RE. Analysis of postoperative complications associated with the use of anti-adhesion sodium hyaluronate-carboxymethylcellulose (HA-CMC) barrier after cytoreductive surgery for ovarian, fallopian tube and peritoneal cancers. Gynecol Oncol. 2011;120:220-3. 